\title{
SI JUKI VS. EMPTY WALLET COMIC ANALYSIS. CRITICAL DISCOURSE REVIEW TEUN A VAN DIJK
}

\author{
Enny Rahayu \\ Universitas Muhammadiyah Sumatera Utara \\ E-mail: ennyrahayu@umsu.ac.id
}

\begin{abstract}
This study aims to describe the Critical Discourse Review of Teun A Van Dijk in the comic Si Juki vs Dompet Blank". This research is a qualitative descriptive study. The method used in this research is the method of data collection and documentation. The data sources in this research are macro structure, super structure, and microstructure which are analyzed directly from the comic Si Juki Vs Dompet Blank. The result of this research is the comic Si Juki Vs Dompet Kososng. From the research results, macro structure, theme; to increase public knowledge about mercury investment. Topics; can start moving to learn to manage finances. Super structure, semantics; In the comic Si Juki Vs Dompet Blank there are two different texts, namely descriptive text, and exposition text. Macro structure; semantics: readers can begin to be moved to learn to manage their finances, stylistics; the choice of words used in the comic Si Juki Vs Dompet Blank is easy to understand because the words used are simple and commonly used in public places, the lexicon; office, boarding, and savings.
\end{abstract}

Keywords: Analysis of Sijuki Comics vs. Kososng Wallet, Review of the Critical Discourse of Teun a Van Dijk, microstructure

\section{INTRODUCTION}

Comics are one of the mass media that can be considered quite effective in conveying messages, compared to other mass communication media. Comics are an art form that uses still images arranged in such a way as to form a story. Picture in this case, drawing a cartoon character (character can be a person, animal, plant or an inanimate object). Usually, comics are printed on paper and accompanied by text. Comics can be published in various forms, ranging from strips in newspapers, published in magazines, to separate books. There are also those who argue that comics are a world of speech, a series of pictures that tell a story.

This image has the same value as reading maps, symbols, diagrams, and so on. There are many types of comic terms, some call it cergam (pictured story), gamer (picture storytelling), and in the academic field of comics it is known as sequential art. Japan knows comics as Manga, and in China it is known as manhua, while in Korea people call it manhwa. From the genre (genre), we can distinguish comics into: superhero comics, romance comics, horror comics, adventure comics, crime comics, comedy comics, humorous comics, action comics, science fiction comics, detective story comics, and comic strips.

Comics in modern times are more commercial in nature and tell a lot of fictional stories, while ancient comics tell a lot about social and spiritual life at that time which tended to be realistic and contain many historical elements, and these comics also became the forerunner to comic world, especially in Indonesia now.

Indonesian comics at the outset can be divided into two broad categories, namely comic strips and comic books, referred to in Marcell Boneff, 2008. Meanwhile, the definition of comic strip itself is an image or series of images containing a story. Comic strips are written and drawn by a cartoonist, and published regularly (usually daily or weekly) in newspapers and on the Internet. In the United Kingdom and Europe, comic strips are also serially published in comic magazines, while the story of a strip is sometimes three or more pages long.

Comics have now developed as a medium in constructing discourse or public opinion that can describe how people live. Comic artists can develop various criticisms and convey information. 
People can also receive information without struggling with theory. Comics that are usually packed with humor and a variety of interesting images are easier to accept. The researcher intends to discuss the comic strip "Si Juki vs Dompet Blank" written by Yahya \& Dede Arkhan or better known as Faza Meonk.

The comic strip "Si Juki vs. Dompet Blank" analyzes critical discourse reviews which is a perspective in taking attitudes in discourse studies involving various disciplines, ranging from discourse analysis, psychology, history, social science to analyze. Critical discourse analysis or abbreviated as AWK, is a new method in social and cultural science research. In January 1991, a symposium which was held for two days in Amsterdam, was attended by several figures including; T. Van Dijk, N. Fairclough, G. Kress, T. Van Leeuwen and R. Wodak, are considered to have inaugurated Critical Discourse Analysis (AWK) as a research method in the social and cultural sciences.

According to Van Dijk, discourse analysis has a systematic and descriptive theoretical purpose, namely the structure and written oral discourse are seen as textual objects and socio-cultural practices between actions and relationships. The model used by Teun A. Van Dijk commonly referred to as social cognition is adopted from a field approach of social psychology. For Van Dijk, research on texts is not only seen on the basis of the text alone, because the text is only the result of production practice which of course needs to be observed.49 So that the formation of a text can describe the structure and process.

"Departing from the above background, it is necessary to carry out more in-depth research on this aspect of the comic story, in order to understand what message is actually being conveyed through the written comics, using a Teun A. Van Dijk discourse approach, as well as to give appreciation to the work of a media worker who of course also has a certain ideology in viewing the reality of life, which is then used as an issue to be highlighted to the public. Based on the explanation above, the researchers chose the title "Analysis of the SiJuki Comics vs. Empty Wallet. Review of the Critical Discourse of Teun A Van Dijk".

\section{LITERATURE REVIEW}

\subsection{Discourse Concept}

Discourse Theory Etymologically, the term discourse as quoted by Dedy Mulyana comes from the Sanskrit wac/wak/vak. Which means 'to say' or to speak'. Then the word changes into discourse. The word 'ana' which is behind is a form of suffix (suffix) which means to distinguish (nominalize).

Thus, the word discourse can be interpreted as a word or speech. In the ancient Javanese Indonesian dictionary written by Wojowasito there is the word waca which means to read, wacaka means to say and the word discourse means to say.

Discourse analysis or discourse analysis is a way or method to examine the discourse contained or contained in communication messages both textually and contextually. Discourse analysis is concerned with the content of communication messages, some of which are in the form of text. In addition, discourse analysis can also allow us to track variations in the ways used by communicators (writers, speakers, directors) in an effort to achieve certain goals or purposes through messages containing certain discourses conveyed.

\subsection{Teun A. Van Dijk's Discourse Analysis Framework}

In fact, many discourse analysis models were introduced and developed by experts Eriyanto (2001) in his discourse analysis book, for example, presenting discourse analysis models developed by Theo Van Leeuwen (1986), Sara Milles (1992), Norman Faiclough (1998), and Teun A. Van Dijk (1998). Of the many discourse analysis models, the Van Dijk model is the most widely used model. Maybe because Van Dijk has elements that can be applied practically.

The model used by Teun A. Van Dijk is often referred to as "social cognition". This term is actually adopted from the field approach of social psychology, especially to explain the structure and 
process of forming a text. The name of this kind of approach cannot be separated from the characteristics of the approach introduced by Van Dijk.

According to Van Dijk, research on discourse is not enough just to be based on analysis or text alone, because text is only the result of a production practice which he must also die. Both text structure, social cognition, and social context are integral parts in Van Dijk's framework.

\subsection{Comic}

Media is a tool or means used to convey messages from communicators to audiences. There are some psychologists who view that in human-to-human communication, the most dominant media in communication are the five human senses, such as the eyes and ears. The messages received by the five human senses are then processed in the human mind to control and determine their attitude towards something, before being expressed in action. (Cangara, 2010:123)

Communication media are intermediary tools in the process of delivering the contents of the statement (message) from the communicator to the communicant or the process of delivering feedback (feedback) from the communicant to the communicator. Communication media that we often encounter in daily life such as leaflets, leaflets, banners, billboards, billboards, posters, newspapers, bulletins, magazines, radio, television, and films. (Cangara, 2010:127)

Comic is an art form that uses still images that are arranged in such a way as to form a story. Drawing in this case, drawing a cartoon character (the character can be a person, animal, plant or an inanimate object). Usually, comics are printed on paper and accompanied by text. Comics can be published in various forms, ranging from strips in newspapers, published in magazines, to separate books. There are also those who think that comics are the world of speech, a series of pictures that tell a story.

\section{IMPLEMENTATION METHOD}

This research is planned for 6 months, starting from March to August 2020. This research is a library research that is not bound by the place where the research is carried out. In this study, the data source is the comic Si Juki vs Dompet Blank.

The data of this research is the process of collecting data or the results obtained from data sources, in this study the data is the analysis of the comic Si Juki vs Dompet Blank with a Critical Discourse Review by Teun A Van Dijk.

This research method is a qualitative descriptive study that aims to analyze the comic Si Juki vs Dompet Blank. With a Critical Discourse Review by Teun A Van Dijk.

\section{RESULTS AND DISCUSSION \\ 4.1 RESULTS \\ 4.1.1 Description of Research Data}

"Below is a description of research data that is closely related to the problems of macro structure, super structure, and micro structure in the comic Si Juki Vs Dompet Blank by Faza Meonk".

Table 4.1 Table of Social Analysis in the Comic Si Juki vs Empty Wallet

\begin{tabular}{|l|l|l|}
\hline $\begin{array}{l}\text { Social Analysis of Discourse on Si } \\
\text { Juki vs Empty Wallet Comics }\end{array}$ & $\begin{array}{l}\text { Things to observe in The Juki vs } \\
\text { Empty Wallet Comic }\end{array}$ & $\begin{array}{l}\text { Elements In The Comic Juki vs } \\
\text { Empty Wallet }\end{array}$ \\
\hline 1. Macro Structure & $\begin{array}{l}\text { Theme ;to increase knowledge } \\
\text { public about mutual fund } \\
\text { investment. }\end{array}$ & $\begin{array}{l}\text { Topics; readers can begin to be } \\
\text { moved to learn to manage their } \\
\text { finances better, get to know } \\
\text { mutual funds, and avoid the } \\
\text { lure of fake investments. }\end{array}$ \\
\hline 2. Super structure & $\begin{array}{l}\text { SCHEMATIC; The findings in } \\
\text { the comic Si Juki Vs Dompet } \\
\text { Blank there are two different } \\
\text { texts, namely descriptive text and }\end{array}$ & $\begin{array}{l}\text { Schema ;n this comic, the } \\
\text { color scheme is used, where the } \\
\text { story of Si Juki Vs Dompet } \\
\text { Blank combines two or more }\end{array}$ \\
\hline
\end{tabular}




\begin{tabular}{|c|c|c|}
\hline & $\begin{array}{l}\text { exposition text. Thus the } \\
\text { superstructure in this study has } \\
\text { differences based on genre. }\end{array}$ & $\begin{array}{l}\text { colors to describe the characters } \\
\text { in the comic Si Yuki Vs } \\
\text { Dompet Kososng. }\end{array}$ \\
\hline \multirow{3}{*}{ 3. Micro Structure } & $\begin{array}{l}\text { SEMANTICS; the meaning you } \\
\text { want It is emphasized in the } \\
\text { comic Si Yuku Vs Dompet Empty } \\
\text { that readers can start to be moved } \\
\text { to learn to manage their finances } \\
\text { better, get to know mutual funds, } \\
\text { and avoid the lure of fraudulent } \\
\text { investments. }\end{array}$ & $\begin{array}{l}\text { Perception; It is recommended } \\
\text { for readers to get used to } \\
\text { managing finances well, don't } \\
\text { let expenses exceed income. } \\
\text { Readers should also not be } \\
\text { fooled by fraudulent } \\
\text { investments. }\end{array}$ \\
\hline & $\begin{array}{l}\text { SYNTAX; The sentences chosen } \\
\text { in the comic Si Yuki Vs. Empty } \\
\text { Wallet are easy to understand and } \\
\text { easy for readers to remember }\end{array}$ & $\begin{array}{l}\text { Sentence form; easy for readers } \\
\text { to understand because the } \\
\text { language } \\
\text { common use }\end{array}$ \\
\hline & $\begin{array}{l}\text { STILISTICS ; The choice of } \\
\text { words used in the comic Si Juki } \\
\text { Vs Dompet Empty is easy to } \\
\text { understand because the words } \\
\text { used are simple and commonly } \\
\text { used in public places }\end{array}$ & $\begin{array}{l}\text { Lexicon ; Office ; boarding } \\
\text { house; residence, temporary } \\
\text { shelter, and savings house; } \\
\text { piggy bank, wallet and tub }\end{array}$ \\
\hline
\end{tabular}

\subsubsection{Analysis Test}

\section{Macro Structure}

"Theme: to increase public knowledge about mutual fund investment. Topic: readers can start to be moved to learn to manage their finances better, get to know mutual funds, and avoid the lure of fake investments".

\section{Super Structure}

Semantics: the findings in the comic Si Juki Vs Dompet Blank there are two different texts, namely descriptive text and exposition text. Thus the super structure in this study has differences based on genre. Thus the building blocks of general descriptive text and section descriptions. The general description section is explained about the definition/identity, the object being discussed. General descriptions in this study were found with varying degrees of success. The description of the part in the description text is explained about the classification of the object being described. Classification in this case is explained by providing clear pictures in more detail. The grouping of section descriptions is determined based on each sentence.

Schema ; in this comic using a color scheme where in the story Si Juki Vs Dompet Blank combines two or more colors in each of the characters in the comic Si Juki Vs Dompet Blank.

\section{Micro Structure}

Semantics: the meaning that you want to emphasize in the comic Si Yuku Vs The Empty Walletreaders can start to be moved to learn to manage their finances better, get to know mutual funds, and avoid the lure of fake investments.

Perception; It is recommended to readers to be able to manage finances well, don't let expenses become bigger than income. Readers should also not be fooled by fraudulent investments.

STILISTICS ; The choice of words used in the comic Si Juki Vs Dompet Blank is easy to understand because the words used are simple and commonly used in public places.

Lexicon ; - Office ; workplace

- boarding house ; shelter, temporary shelter, and home

- Savings ; piggy bank, wallet and good

- Money Laundering: money from dirty work

SYNTAX ; The sentences chosen in the comic Si Yuki Vs. Empty Wallet are easy to 
understand and easy for readers to remember

Sentence form; easy to understand by readers because the language used is common.

\subsubsection{Hypothesis Testers}

Based on the research above, the researcher obtained the overall results of the research data on the problems of macro structure, super structure, and micro structure in the comic Si Juki Vs Dompet Blank by Faza Meonk.

\subsection{DISCUSSION}

Based on the results of the research and discussions that have been determined by the researcher, the study discusses the existence of macro structures, super structures, and micro structures in the comic Si Juki Vs Dompet Blank by Faza Meonk.

\section{CONCLUSION}

Based on the results and discussion in the research on problem analysis in the comic Si Juki Vs Dompet Blank by Faza Meonk, the conclusions include;

1. Literary works are created and poured through various means and have beautiful values. Literary works are created with the imagination of various parties who create based on their environment and personal experiences faced.

2. The analysis used in this research is the comic Si Juki Vs Dompet Blank by Faza Meonk consisting of descriptive text and sexposition text.

\section{REFERENCES}

Ajidarma, Seno Gumira. Ketika Jurnalisme Dibungkam Sastra Harus Dibicara. Yogyakarta: Bentang. Edisi Kedua. September 2005.

Arikunto, Suharsimi. Prosedur Penelitian: Suatu Pendekatan Praktek. Jakarta: PT. Rineka Cipta,2002.

Depdiknas, Pusat Pembinaan dan Pengembangan Bahasa. Pedoman Umum Ejaan Bahasa Indonesia yang Disempurnakan dan Pedoman Umum Pembentukan Istilah. Bandung: M2S. Cetakan Kedua. Februari 2004.

Djuroto, Totok Manajemen Penerbitan Pers. Bandung: Rosda, 2004. Eriyanto. Analisis Wacana Pengantar Analisis Teks Media. Yogyakarta: LKiS, Cet VII Februari2009.

Harsono, Andreas dan Budi Setiyono, ed. Jurnalisme Sastrawi: Antologi Liputan Mendalam dan Memikat. Jakarta: KPG, 2008.

Hernawan, J. Budi dan Poengky Indarti dkk, Laporan Praktek Penyiksaan di Aceh dan Papua19982007. Jakarta: Imparsial, 2009.

Hersey, John. Hiroshima: Ketika Bom Dijatuhkan. Jakarta: Komunitas Bambu. 2008. HM, Zaenuddin. The Journalist. Jakarta: Prestasi Pustaka, 2007.

Ishwara, Luwi. Catatan-Catatan Jurnalisme Dasar. Jakarta: Kompas. Desember 2005. Kovach,Bill dan Tom Rosentiel. Sembilan Elemen Jurnalisme Apa yang Seharusnya Diketahui Wartawan dan Diharapkan Publik. Jakarta: Yayasan Pantau. Cetakan Ketiga. 2006.

Kurnia, Septiawan Santana. Jurnalisme Sastra. Jakarta: PT. Gramedia Pustaka Utama, 2002. Majalah Pantau Kajian Media dan Jurnalisme Tahun III No.025-Mei 2002. Jakarta: Institut Studi Arus Informasi. 2002.

Muhtadi, Asep Saeful. Jurnalistik Pendekatan Teori dan Praktik. Jakarta: Logos, 1999. https://kangmastopik.wordpress.com/2011/06/18/ideologi-media-komikfilm-film-indie/ 
Volume 1 No 2 (2021)

Si Juki vs Empty Wallet Comic Analysis. Critical Discourse Review Teun A Van Dijk DOI: $10.54443 /$ ijerlas.v1i2.90 